\title{
PENGARUH PARTISIPASI DAN KOMITMEN ORGANISASI TERHADAP KINERJA MANAJERIAL: KOMITMEN ORGANISASI SEBAGAI VARIABEL MODERETING
}

\author{
Yulia Putri \\ Universitas Trilogi \\ yuliaputri242@gmail.com \\ Novita \\ Universitas Trilogi \\ novita_1210@trilogi.ac.id
}

\begin{abstract}
This study aims to determine: Effect of Budget Participation on Managerial Performance, Effect of Organizational Commitment on Managerial Performance, Effect of Organizational Commitment to Moderate the Relationship Between Budget Participation and Managerial Performance. The research data was collected using questionnaire techniques. The number of samples in this study were 42 respondents Structural Officials at one of the private universities in Jakarta. The sampling technique uses purposive sampling.Data analysis method uses Partial Least Square (PLS) method, the analysis is carried out through three stages, namely outside model analysis, internal model analysis, and hypothesis testing. The results of this study indicate the effect of budgeting participation has a positive and significant effect on managerial performance, the second hypothesis shows organizational commitment has a positive and significant effect on managerial performance, and the third hypothesis indicates that moderate organizational commitment has a positive influence and significant influence on participation participation relationships budget with managerial performance.
\end{abstract}

Keyword: Budget participation, organizational commitment, managerial performance

\begin{abstract}
Abstrak
Penelitian ini bertujuan untuk mengetahui: Pengaruh partisipasi anggaran terhadap kinerja manajerial, Pengaruh komitmen organisasi terhadap Kinerja Manajerial, Pengaruh komitmen organisasi memoderasihubungan antara partisipasi anggaran dan kinerja manajerial. Data penelitian dikumpulkan menggunakan teknik kuesioner. Jumlah sampel dalam penelitian adalah 42 responden pejabat struktural di salah satu perguruan tinggi swasta di Jakarta teknik pengambilan sampel menggunakanpurposive sampling. Metode analisis data menggunakan metode Partial Least Square (PLS), analisis dilakukan melalui tiga tahap yaitu analisa outer model, analisa inner model, dan pengujian hipotesa. Hasil
\end{abstract}


dari penelitian ini menunjukkan partisipasi anggaran memiliki pengaruh positif dan signifikan terhadap kinerja manajerial, hipotesa kedua menunjukkan komitmen organisasi berpengaruh positif dan signifikan terhadap kinerja manajerial, dan hipotesa ketiga menunjukkan bahwa variabel moderasi komitmen organisasi berpengaruh positif dan signifikan terhadap hubungan partisipasi anggaran dengan kinerja manajerial.

\section{Kata kunci: Partisipasi anggaran, komitmen organisasi, kinerja manajerial}

\section{PENDAHULUAN}

Saat ini kondisi persaingan di bidang pendidikan khususnya perguruan tinggi swasta semakin kompetitif. Masyarakat sering membandingkan perguruan tinggi swasta yang satu dengan yang lain untuk menjadi pilihannya dalam melanjutkan pendidikan. Untuk mendapatkan kepercayaan dari masyarakat setiap universitas swasta harus meningkatkan kualitas dari dosen, mahasiswa, pelayanan akademik, sarana dan prasarana. Agar lulusan yang dihasilkan bisa memenuhi kebutuhan dunia kerja, salah satu cara dengan meningkatkan eksistensi dari perguruan tinggi swasta di Jakarta kepada masyarakat, dan seharusnya perguruantinggi swasta melakukan pembenahan disegala bidang, salah satunya dengan meningkatan efektivitas dan efisiensi dalam bidang manajemen. Dalam bidang manajemen untuk mengukur keberhasilan seorang manajer yaitu dengan pengendalian administratif yang salah satunya dilakukan melalui proses penganggaran pada setiap perguruan tinggi (Zahro \&Januarti, 2016). Peruruan tinggi swasta di Jakarta merupakan lembaga pendidikan yang ada dibawah naungan koordinasi Kopertis, yang aktivitasnya tidak lepas dari masalah penganggaran dan partisipasi pejabat struktural dalam penyusunan anggaran sangat dibutuhkan agar kinerja manajerial dapat meningkat.

Proses penyusunan anggaran yang efektif sebaiknya disusun berdasarkan metode top down dan bottom upatau dapat disebut dengan partisipasi anggarandimana pembuat anggaran dalam hal ini manajer tingkat bawah membuat anggaran yang diperlukan dan manajer tingkat atas meninjau dan memastikan bahwa anggaran yang telah dibuat dapat dipertanggungjawabkan dan telah sesuai dengan tujuan dari keseluruhan organisasi (Anthony N \& Govindarajan, 2011). Partisipasi penganggaran merujuk kepada tingkat pengaruh dan keterlibatan yang dirasakan individu dalam proses perancangan anggaran.

Partisipasi anggaran juga ditentukan oleh komitmen pelaksananya, ketika individu mengejar kepentingan pribadi yakni memiliki komitmen organisasional rendah, maka individu tersebut dalam akan berpartisipasi dalammenyusun anggaran agar kinerjanya terlihat baik, sehingga akan meningkatkan kinerja manajerial, dengan kata lain bahwa komitmen 
organisasional mampu mempengaruhi hubungan partsipasi anggaran terhadap Kinerja manajerial.

Masalah yang akan dibahas adalah apakah partisipasi anggaran mempengaruhi kinerja manajerial di salah satu perguruan tinggi swasta, apakah komitmen organisasi berpengaruh terhadap kinerja manajerial di salah satu perguruan tinggi swasta, dan apakah komitmen organisasi dapat memoderasi hubungan partisipasi anggaran terhadap kinerja manajerial, dengan mengetahui masalah yang akan dibahas maka tujuan penelitian ini adalah Untuk mengatahui bagaimana partisipasi anggaran berpengaruh terhadap kinerja manajerial, bagaimana komitmen organisasi berpengaruh terhadap kinerja manajerial, dan bagaimana komitmen organisasi memoderasi hubungan partisipasi anggaran terhadap kinerja manajerial.

\section{TELAAH LITERATUR DAN PENGEMBANGAN HIPOTESIS}

\section{PARTISIPASI ANGGARAN}

Menurut (Hansen, Don R. dan Mowen, 2013)partisipasi anggaran adalah pendekatan penganggaran yang memungkinkan para manajer yang akan bertanggungjawab atas kinerja anggaran, untuk berpartisipasi dalam pengembangan anggaran, partisipasi anggaran mengkomunikasikan rasa tanggungjawab kepada para manajer tingkat bawah dan mendorong kreativitas. Di dalam menyusun anggaran harus diperhatikan implikasi atau keterlibatan aspek perilaku manusia. Kesuksesan anggaran hanya dapat dicapai jika semua pelaksana secara simpatik mau membantu, bekerja sama, dan bersungguh-sungguh dalam melaksanakan anggaran.

\section{KOMITMEN ORGANISASI}

Mathis dan Jackson dalam Sopiah (2008:155) mendefinisikan komitmen organisasional sebagai derajat dimana karyawan percaya dan mau menerima tujuan-tujuan organisasi dan akan tetap tinggal atau tidak akan meninggalkan organisasinya.

Mowday dalam Sabrina (2011) yang dikutip Kurniawan (2013:7) mengemukakan bahwa komitmenorganisasi terbangun apabila masingmasing individu mengembangkan tiga sikap yang saling berhubungan terhadap organisasi, yang antara lain adalah: (1) Identifikasi: pemahaman atau penghayatan terhadap tujuan organisasi, (2) Keterlibatan: perasaan terlibat dalam suatu pekerjaan atau perasaan bahwa pekerjaan tersebut adalah menyenangkan. (3) Loyalitas: perasaan bahwa organisasi adalah tempatnya bekerja dan tinggal. 


\section{KINERJA MANAJERIAL}

Menurut (Hansen, Don R. dan Mowen, 2013)kinerja manajerial memiliki indikator sebagai berikut: (1) Perencanaan: Kegiatan manajerial yang disebut perencanaan adalah perumusan tindakan terinci untukmencapai tujuan tertentu, diperlukan penetapan tujuan dan identifikasi metode untuk mencapai tujuan tersebut, (2) Pengendalian: adalah kegiatan manajerial untuk memantau implementasi rencana dan mengambil tindakan korektif sesuai kebutuhan. Kontrol biasanya dicapai dengan menggunakan umpan balik, (3) Pengambilan Keputusan, Proses memilih di antara alternatif yang bersaing adalah pengambilan keputusan. Fungsi manajerial ini terkait dengan perencanaan dan pengendalian. Seorang manajer tidak dapat merencanakan tanpa membuat keputusan. Manajer harus memilih di antara tujuan dan metode yang bersaing untuk melaksanakan tujuan yang dipilih.

\section{PENGARUH PARTISIPASI ANGGRAN TERHADAP KINERJA MANAJERIAL}

Menurut Basri (2011:24) partisipasi banyak memberikan dampak positif terhadap kinerja manajerial, salah satunya adalah dapat meningkatkan kinerja manajer, hal ini disebabkan manajer merasa bertanggung jawab atas capaian anggaran yang disusunnya. Manfaat lainnya yang diutarakan Basri adalah dapat meningkatkan kebersamaan para manajer dalam mencapai tujuan anggaran disebabkan anggaran yang ditetapkan adalah anggaran yang dibuat bersama. Maka hipotesa dalam penelitian ini:

H1: Partisipasi anggaran berpengaruh terhadap kinerja manajerial.

\section{PENGARUH KOMITMEN ORGANISASI TERHADAP KINERJA MANAJERIAL}

Armstrong (2009) menyatakan bahwa pengertian komitmen mempunyai 3 perilaku terkait dengan perusahaan tempat seseorang bekerja. Perilaku tersebut adalah: Kepercayaan, Keinginan untuk bekerja, dan keinginan untuk bertahan dan menjadi bagian dari organisasi.

$\mathrm{H} 2$ : Komitmen organisasi berpengaruh terhadap kinerja manajerial

\section{PENGARUH KOMITMEN ORGANISASI MEMODERASI HUBUNGAN ANTARA PARTISIPASIANGGARAN TERHADAPKINERJA}

\section{MANAJERIAL}

Partisipasi anggaran juga ditentukan oleh komitmen pelaksananya, ketika individu mengejar kepentingan pribadi yakni memiliki komitmen organisasional rendah, maka individu tersebut dalam partisipasi penganggaran akan berusaha melakukan senjangan anggaran agar kinerjanya terlihat baik, sehingga akan meningkatkan kinerja manajerial, 
dengan kata lain bahwa komitmen organisasional mampu mempengaruhi hubungan partsipasi anggaran terhadap Kinerja manajerial.

H3: Komitmen organisasi memoderasi hubungan antara partisipasi anggaran terhadap kinerja manajerial.

\section{METODE PENELITIAN}

\section{OBJEK PENELITIAN \\ Populasi}

Menurut (Sugiyono, 2014), populasi adalah wilayah generalisasi yang terdiri atas objek atau subyek yang mempunyai kuantitas dan karakteristik tertentu yang ditetapkan oleh peneliti untuk dipelajari dan kemudian ditarik kesimpulannya.Populasi pada penelitian ini adalah seluruh pejabat yang terlibat dalam penyusunan anggaran di lingkungan salah satu Perguruan Tinggi Swasta di Jakarta.

\section{Sampel}

Dalam penelitian ini sampel dipilih dengan menggunakan teknik purposive sampling dengan responden wakil rektor, dekan fakultas, kepala bagian, kepala bagian program studi, sekretaris dan humas Perguruan Tinggi Swasta di Jakarta yang berjumlah sekitar 30-50 orang (Studi kasus pada salah satu Perguruan Tinggi Swasta di Jakarta). Penelitian ini menggunakan jenis data primer dengan metode kuesioner.

\section{METODE PENGUMPULAN DATA Observasi}

Dalam hal ini penulis melakukan observasi secara langsung untuk melihat kondisi perguruan tinggi swasta, Sturuktur organisasi, maupun kegiatan kerja karyawan (Studi kasus pada salah satu Perguruan Tiggi Swasta di Jakarta.

\section{Kuesioner}

Kuisoner ini terbagi menjadi dua bagian, yaitu bagian pertama merupakan data diri responden dan bagian kedua merupakan pertanyaanpertanyaan yang berkaitan dengan variabel penelitian (Partisipasi anggaran, Komitmen Organisasi dan kinerja manajerial).

Skala pengukuran untuk variabel $\mathrm{X} 1, \mathrm{X} 2$ variabel $\mathrm{Y}$, dan juga Variabel Moderating dengan menggunakan tipe skala "Likert". Tipe skala likert menggunakan skala enam poin. Terdiri dari "sangat tidak setuju sekali", "sangat tidak setuju", "tidak setuju", " setuju", "sangat setuju", dan "sangat setuju sekali". Tipe Likert digunakan untuk mengukur sikap, pendapat dan persepsi seseorang atau kelompok tentang fenomena sosial (Sugiyono, 2014). 


\section{ANALISIS DATA}

\section{Statistik Deskriptif}

Untuk memberikan gambaran mengenai demografi responden penelitian (umur, jenis kelamin, jabatan, jumlah bawahan, pendidikan, dan pengalaman kerja) dan deskripsi mengenai variabel-variabel penelitian.

\section{Analisis Verifikatif}

Analisis verifikatif merupakan analisis untuk membuktikan dan mencari kebenaran dari hipotesis yang diajukan. Pengujian hipotesis dalam penelitian ini menggunakan metode Partial Least Square (PLS) sumber buku SmartPLS penerbit(Ghozali, 2015).. Keunggulan metode ini adalah tidak memerlukan asumsi dan dapat diestimasi dengan jumlah sampel yang relatif kecil. Program yang digunakan sebagai alat bantu berupa SmartPLS versi 3.2.7 yang dirancang untuk mengetimasi persamaan struktural. Analisis dilakukan melalui tiga tahap yaitu analisa outer model, analisa inner model, dan pengujian hipotesa.

\section{Variabel Penelitian}

Tabel 1

Variabel Penelitian

\begin{tabular}{|c|c|c|}
\hline Variabel & $\begin{array}{c}\text { Sub } \\
\text { Variabel }\end{array}$ & Indikator \\
\hline Independen & $\begin{array}{l}\text { Partisipasi } \\
\text { Anggaran }\end{array}$ & $\begin{array}{l}\text { 1. Kemampuan memberikan } \\
\text { pendapat dalam penyusunan } \\
\text { program kerja dan anggaran } \\
\text { 2. Frekuensi memberikan dan } \\
\text { menerima pendapat/usulan } \\
\text { kepada/dari atasan terhadap } \\
\text { program kerja dan anggaran } \\
\text { 3. Konstribusi dalam penyusunan } \\
\text { program kerja dan anggaran }\end{array}$ \\
\hline Dependen & $\begin{array}{l}\text { Kinerja } \\
\text { Manajerial }\end{array}$ & $\begin{array}{l}\text { 1. Perencanaan Program Kerja dan } \\
\text { Anggaran } \\
\text { 2. Pengendalian Program Kerja dan } \\
\text { Anggaran } \\
\text { 3. Pengambilan Keputusan dalam } \\
\text { Program Kerja dan Anggaran }\end{array}$ \\
\hline Moderating & $\begin{array}{l}\text { Komitmen } \\
\text { Organisasi }\end{array}$ & $\begin{array}{l}\text { 1. Affective commitment } \\
\text { 2. Continuance commitment } \\
\text { 3. Normatif commitment }\end{array}$ \\
\hline
\end{tabular}

Sumber: Data Diolah, 2018 


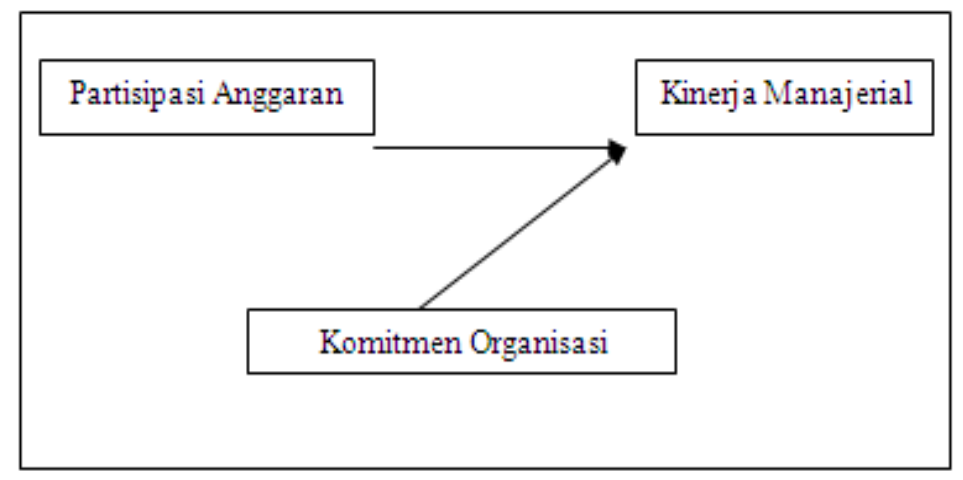

Gambar 1

Kerangka Konseptual

Sumber: Data Diolah, 2018

\section{HASIL PENELITIAN DAN PEMBAHASAN}

\section{ANALISIS STATISTIK DESKRIPTIF Variabel Partisipasi Anggaran}

Variabel partisipasi anggaran terdiri dari 3 indikator, indikator pertama yaitu kemampuan memberikan pendapat dalam penyusunan program kerja dan anggaran, frekuensi memberikan dan menerima pendapat/usulan kepada/dari atasan terhadap program kerja dan anggaran, dan kontribusi dalam penyusunan program kerja dan anggaran

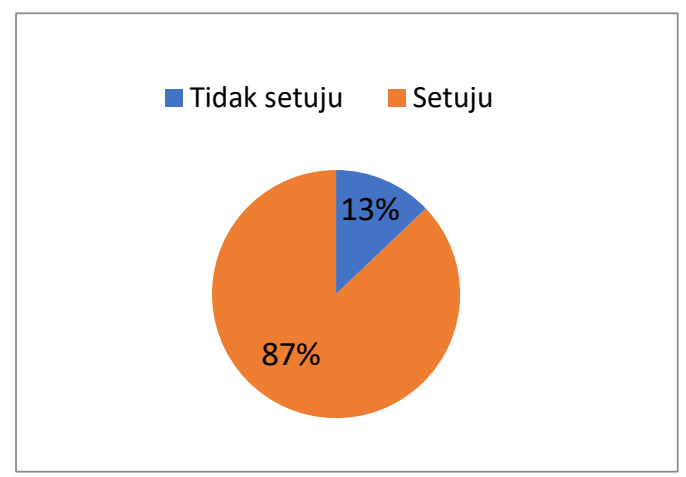

\section{Gambar 2}

Tanggapan Responden pada Variabel

Partisipasi Anggaran

Sumber: Pengolahan data kuesioner, 2018

Gambar 2 menunjukkan responden yang tidak setuju dengan variabel ini sebesar $13 \%$ dan $87 \%$ responden menyatakan setuju terhadap variabel partisipasi anggaran. Artinya pada indikator pertama pejabat struktural mampu memberikan pendapat dalam penyusunan program kerja dan anggaran pada unit kerja masing-masing, pada indikator kedua juga menunjukan bahwa frekuensi dalam memberikan pendapat maupun 
menerima pendapat/usulan kepada/dari atasan telah diterapkan dan dilaksanakan dengan baik oleh pejabat struktural salah satu Perguruan Tinggi Swasta di Jakarta dalam menyusun program kerja dan anggaran, dan pada indikator ketiga pejabat struktural salah satu Perguruan Tinggi Swasta di Jakarta sangat berkontribusi dalam merencanakan serta menyusun program kerja dan anggaran setiap tahunnya.

\section{Variabel Komitmen Organisasi}

Variabel komitmen organisasi terdiri dari 3 indikatoraffective commitment, continuance commitment, normative commitment. Gambar 3 menunjukkan hasil responden yangsetuju dengan variabel ini sebesar $91 \%$ dan responden yang tidak setuju sebesar $9 \%$.

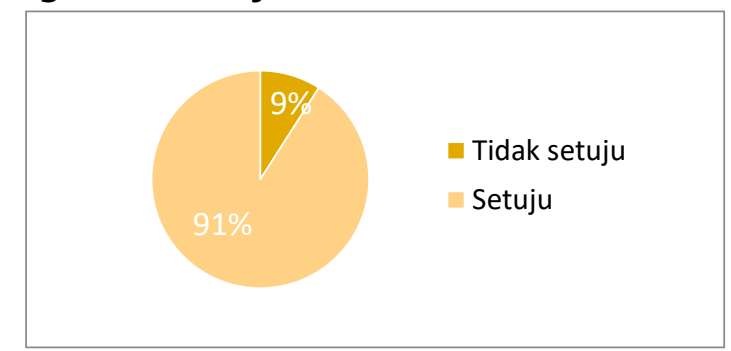

\section{Gambar 3}

Tanggapan Responden pada Variabel Komitmen Organisasi

Sumber: Pengolahan data kuesioner, 2018

Artinya dari presentase tersebut pada indikator pertama responden setuju bahwa tujuan dan nilai di dalam organisasi sesuai dengan diri mereka, serta mereka mendukung tujuan tersebut, responden merasa harus tetap bergabung dengan salah satu Perguruan Tinggi Swasta di Jakarta karena nilai ekonomi yang dirasa harus diperhitungkan jika meninggalkan organisasi, dan bersedia membantu untuk mencapainya, dan pada indikator ketiga responden merasa bahwa loyalitas, tangungjawab dan integritas sangat penting dan harus dimiliki oleh seluruh karyawan dalam menjalankan tugas dan kewajibannya.

\section{Kinerja Manajerial}

Variabel Dependen kinerja manajerial terdiri dari 3 indikator yaitu perencanaan program kerja dan anggaran, pengendalian program kerja dan anggaran, dan pengambilan keputusan dalam program kerja dan anggaran. 


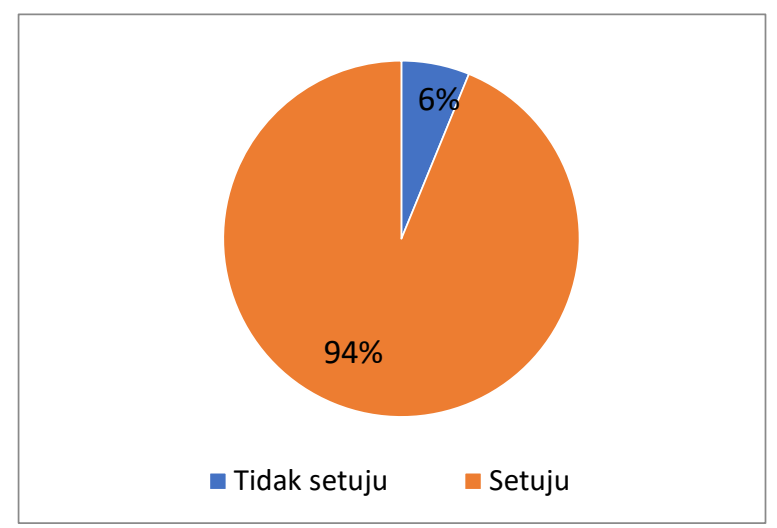

\section{Gambar 4}

Tanggapan Responden pada Variabel Kinerja Manajerial

Sumber: Pengolahan data kuesioner, 2018

Gambar 4 menunjukkan responden yang setuju dengan variabel ini sebesar $94 \%$ dan responden yang tidak setuju sebesar $6 \%$.Artinya indikator pertama menunjukkan bahwa manajerial di salah satu Perguruan TinggiSwasta di Jakarta telah melakukan rencana, menentukan tindakan, dan mengidentifikasi metode untuk mencapai tujuan dari institusi.Pada indikator kedua menunjukkan bahwa manajerial salah satuPerguruan Tinggi Swastadi Jakarta telah melakukan pengendalian untuk memantau rencana serta mengawasi setiap kegiatan yang ada di institusi maupun dalam perencanaan program kerja dan anggaran, serta pada indikator ketiga menunjukan manajerial Perguruan Tinggi tas Swastatelah melakukan evaluasi dan juga pengawasan untuk pengambilan keputusan disetiap perencanaan program kerja dan anggaran.

\section{ANALISIS MODEL STRUKTURAL}

Teknik pengolahan data dengan menggunakan metode Partial Least Square (PLS) menggunakan aplikasi SmartPLS versi 3. Tahap-tahap analisis model struktural adalah sebagai berikut: 


\section{AnalisisOuter Model}

Uji Validitas

Convergent Validity

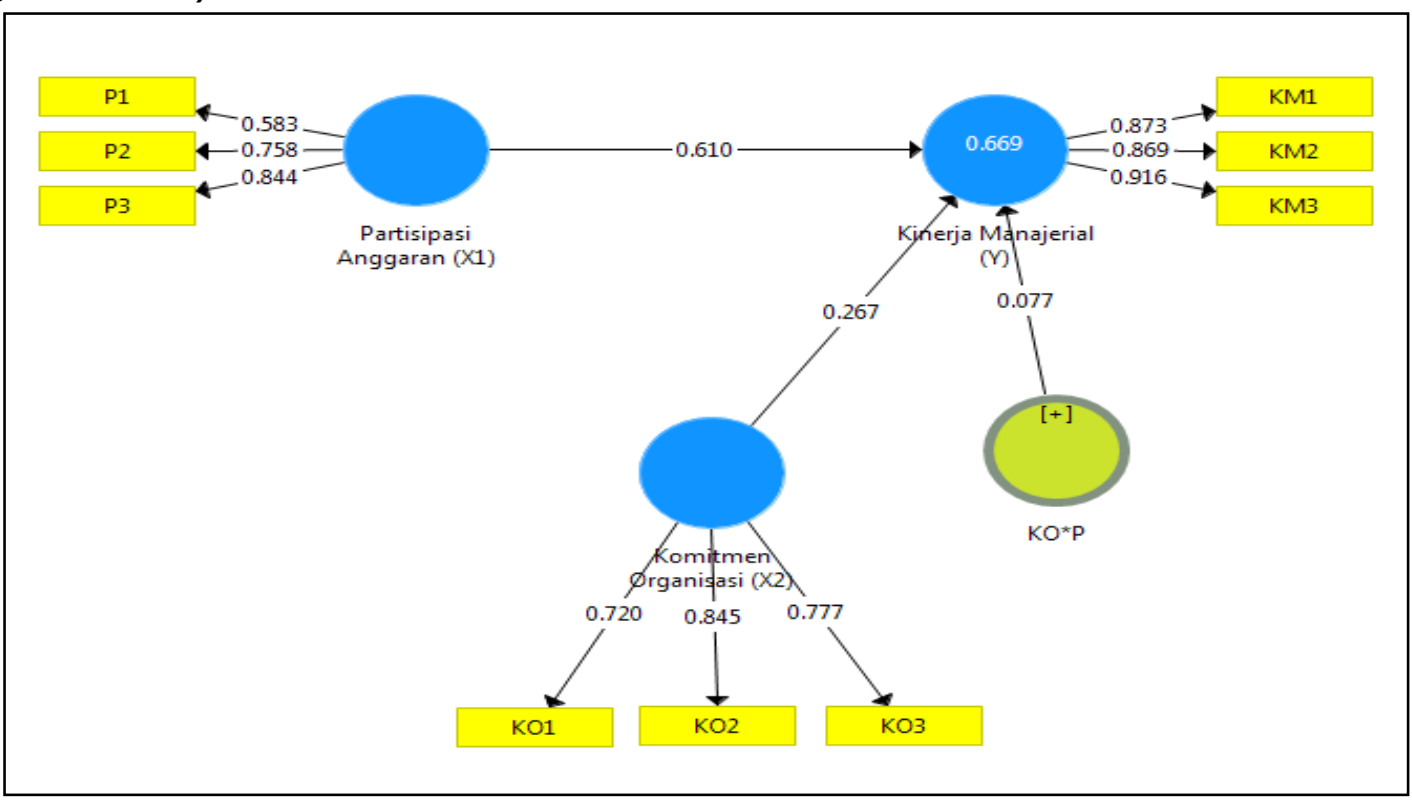

\section{Gambar 5 \\ Nilai Loading Factors}

Sumber: Data kuesioener, diolah dengan SmartPLS, 2018

Tabel 2

\section{Outer Loadings}

\begin{tabular}{|l|c|c|c|c|}
\hline & $\begin{array}{c}\text { Kinerja } \\
\text { Manajerial }\end{array}$ & $\begin{array}{c}\text { Komitmen } \\
\text { Organisasi }\end{array}$ & $\begin{array}{c}\text { Moderating } \\
\text { Effect }\end{array}$ & $\begin{array}{c}\text { Partisipasi } \\
\text { Anggaran }\end{array}$ \\
\hline KM1 & 0,873 & & & \\
\hline KM2 & 0,869 & & & \\
\hline KM3 & 0,916 & & & \\
\hline K01 & & 0,720 & & \\
\hline K02 & & 0,845 & & 0,583 \\
\hline KO3 & & 0,777 & & 0,758 \\
\hline P1 & & & & 0,844 \\
\hline P2 & & & & \\
\hline P3 & & & & \\
\hline KO*P & & & 1,000 & \\
\hline
\end{tabular}

Sumber: Data kuesioner, diolah dengan SmartPLS, 2018

Nilai Convergnt validity dapat dilihat dari nilai loading factor pada variabel laten dengan indikator-indikatornya. Dengan korelasi nilai yang diharapkan yaitu lebih dari 0,70 dengan konstruk yang diukur (Ghozali, 2015). padaGambar 4.4 dan Tabel 4.1, Nilai outer loadings pada awalnya belum memenuhi convergent validity karena masih ada indikator yang 
memiliki nilai loading factor dibawah 0,7 . Indikator yang masih belum memenuhi nilai loading factor yang ditentukan adalah indikator P1 dengan nilai loading factors sebesar 0,583. Agar dapat memenuhi penilaian convergent validity, maka model harus dimodifikasi. Modifikasi model dilakukan dengan cara mengeluarkan indikator-indikator yang sudah disebutkan di atas yang memiliki nilai loading factor dibawah 0,7. Agar dapat memenuhi penilaian convergent validity, maka model harus dimodifikasi hasilnya dapat lihat pada Gambar 6:

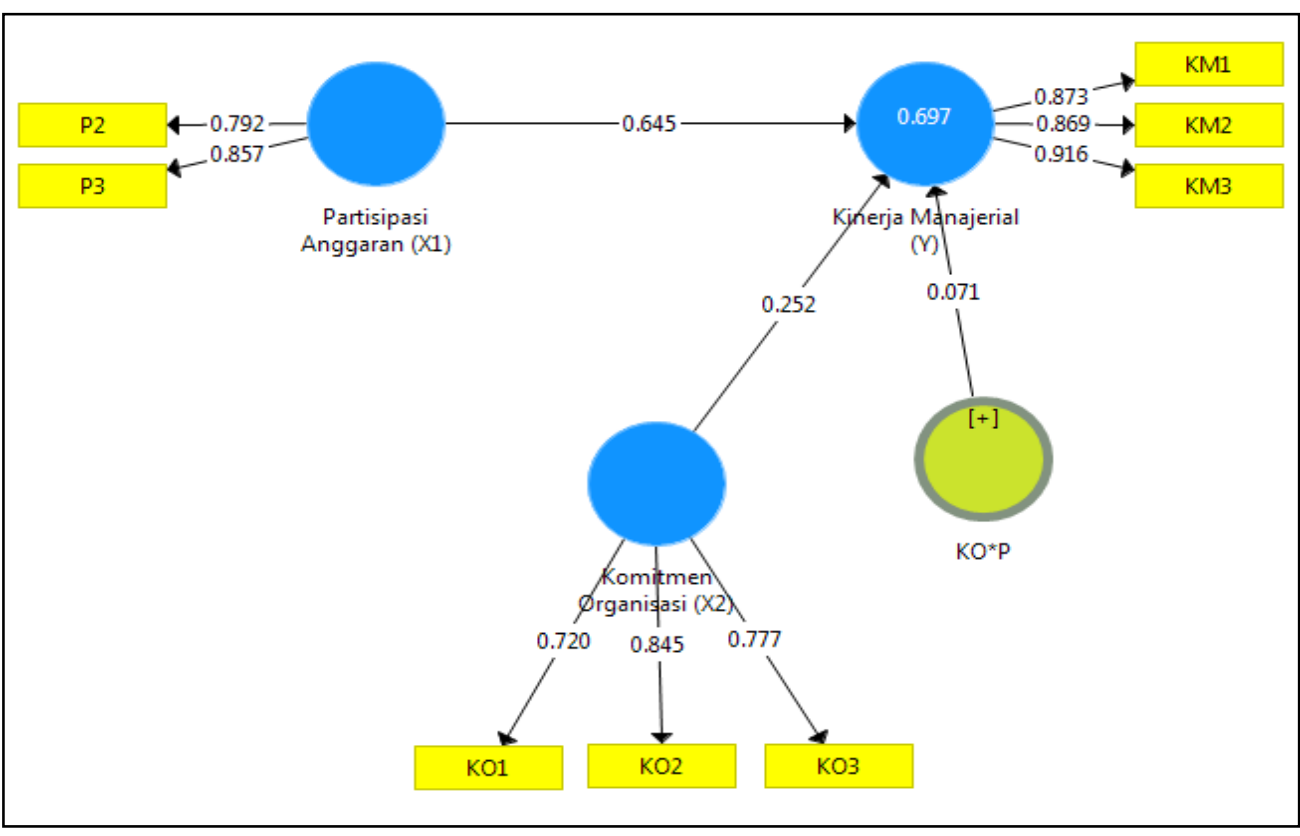

Gambar 6

Nilai Loading Factors Eliminasi

Sumber: Data kuesioener, diolah dengan SmartPLS, 2018

Seperti yang terlihat pada Gambar 6 seluruh indikator sudah memiliki nilai loading factor di atas 0,7 , sehingga sudah tidak ada lagi indikator yang harus dieliminasi, terdapat $37,5 \%$ indikator yang memiliki nilai loading factor diatas 0.70 dengan kisaran $0.70-0.79$. Dan $62,5 \%$ sisanya memiliki nilai loading factor yang sangat tinggi dengan kisaran $0.80-0.90$. Sehingga menunjukan validitas yang sangat baik.

a) Discriminant validity, dan Average varience extracted (AVE)

Disciminant validity dapat dilakukan dengan melihat nilai cross loadingfactor untuk mengetahui bahwa konstruk memiliki diskriminan yang memadai. Dengan cara membandingan korelasi indikator suatu konstruk tersebut dengan konstruk lainnya.Jika korelasi konstruk memiliki nilai yang lebih tinggi dibandingkan dengan korelasi indikator tersebut terhadap konstruk lain, maka dikatakan konstruk memiliki discriminant validity yang tinggi (Ghozali, 2015). 
Tabel 3

Cross Loading

\begin{tabular}{|l|c|c|c|}
\hline & $\begin{array}{c}\text { Kinerja } \\
\text { Manajerial }\end{array}$ & $\begin{array}{c}\text { Komitmen } \\
\text { Organisasi }\end{array}$ & $\begin{array}{c}\text { Partisipasi } \\
\text { Anggaran }\end{array}$ \\
\hline KM1 & 0,873 & 0,505 & 0,741 \\
\hline KM2 & 0,869 & 0,611 & 0,698 \\
\hline KM3 & 0,916 & 0,673 & 0,696 \\
\hline KO1 & 0,433 & 0,720 & 0,466 \\
\hline KO2 & 0,603 & 0,845 & 0,549 \\
\hline KO3 & 0,528 & 0,777 & 0,467 \\
\hline P2 & 0,603 & 0,407 & 0,792 \\
\hline P3 & 0,716 & 0,622 & 0,857 \\
\hline KO*P & 0,115 & 0,167 & $-0,016$ \\
\hline
\end{tabular}

Terlihat pada tabel 3 dapat disimpulkan bahwa semua indikator mempunyai koefisien korelasi yang lebih besar dengan masingmasing konstruknya dibandingkan dengan nilai koefisein korelasi indikator pada blok konstruk pada kolom lainnya. Seperti konstruk kinerja manajerial dengan indikatornya KM1, KM2 dan KM3 nilainya lebih tinggi dibandingkan dengan indikator pada kolerasi komitmen organisasi dan partisipasi anggaran. Sama halnya dengan konstruk komitmen organisasi dengan indikator $\mathrm{KO} 1, \mathrm{KO} 2, \mathrm{KO} 3$ nilainya lebih tinggi dibandingkan dengan indikator pada korelasi kinerja manajerial dan partisipasi anggaran. Dan pada konstruk partisipasi anggaran dengan indikator P2, P3 juga memiliki nilai yang lebih tinggi dibandingkan dengan indikator pada korelasi kinerja manajerial dan komitmen organisasi. Metode lain untuk menilai discriminant validity, yaitu dengan melihat padaAverage Varience Extracted (AVE) pada Tabel 4.3 berikut:

Tabel 4

Construct Reliability dan Validity

\begin{tabular}{|l|c|c|c|}
\hline & $\begin{array}{l}\text { Composite } \\
\text { reliability }\end{array}$ & $\begin{array}{l}\text { Cronbach's } \\
\text { alpha }\end{array}$ & $\begin{array}{l}\text { Average } \\
\text { variance } \\
\text { extrated } \\
\text { (AVE) }\end{array}$ \\
\hline $\begin{array}{l}\text { Kinerja } \\
\text { Manajerial }\end{array}$ & 0,916 & 0,863 & 0,785 \\
\hline $\begin{array}{l}\text { Komitmen } \\
\text { Organisasi }\end{array}$ & 0,825 & 0,683 & 0,612 \\
\hline KO*P & 0,791 & 0,832 & 0,401 \\
\hline $\begin{array}{l}\text { Partisipasi } \\
\text { Anggaran }\end{array}$ & 0,810 & 0,534 & 0,681 \\
\hline
\end{tabular}

Sumber: Data kuesioner, diolah dengan SmartPLS, 2018 
Berdasarkan Tabel 4 tersebut, memiliki nilai AVE antara indikator dengan konstruknya lebih dari 0.50 untuk semua konstruk. Kinerja Manajerial (KM) memiliki nilai AVE 0.785, Komitmen Organisasi (KO) sebesar 0.612, Partisipasi Anggaran (P) sebesar 0.681, dan KO*P sebesar 0,401 Sehingga korelasi antara indikator dengan konstruknya memiliki discriminant validity yang baik.

\section{Uji Reliabilitas}

\section{Composite reliability}

Composite reliability merupakan pengujian untuk mengetahui apakah indikator-indikator yang membangun kontruks penelitian, memiliki nilai reliabilitas atau tidak. Kriteria yang digunakan, yaitu jika indikator yang membangun konstruk memiliki nilai composite reliability lebih besar dari 0.70 maka data yang digunakan memiliki reliabilitas yang tinggi (Ghozali, 2015). Dapat dilihat pada Tabel 4.3 untuk konstruk KM memiliki nilai sebesar 0,916, KO sebesar 0,825, P sebesar 0,810, dan KO*P sebesar 0,791 . Sehingga dapat disimpulkan bahwa semua konstruk memenuhi kriteria composite reliability dan memiliki nilai reliabilitas yang tinggi.

\section{Cornbach's alpha}

Uji reliabilitas juga dapat diperkuat dengan Cornbach A/pha. Dengan kriteria nilai yang diharapkan yaitu di atas 0.70 (Ghozali, 2015). Dari Tabel 4.12 dapat dilihat bahwa konstruk KM memiliki nilai Cornbach A/pha sebesar 0,863 , KO sebesar 0.879 dan KO*P memiliki nilai 0,832. Sehingga dapat disimpulkan bahwa semua konstruk memenuhi kriteria Cornbach Alpha dan memiliki nilai reliabilitas yang tinggi.

\section{AnalisisInner Model}

\section{Path Coefficient}

Tabel 5 menunjukan bahwa konstruk Partisipasi Anggaran memiliki pengaruh positif terhadap konstruk endogen Kinerja Manajerial (KM) dengan nilai sebesar 0.623 . Konstruk Komitmen Organisasi (KO) memiliki pengaruh positif terhadap KM dengan nilai sebesar 0.243. Konstruk KO*P memiliki pengaruh positif terhadap KM sebesar 0.093. Sehingga dapat disimpulkan bahwa semua konstruk laten berpengaruh positif terhadap konstruk endogen yaitu Kinerja Manajerial (KM). 
Tabel 5

Nilai Path Coefficient

\begin{tabular}{|l|c|c|c|}
\hline & $\begin{array}{c}\text { Partisipasi } \\
\text { Anggaran }\end{array}$ & $\begin{array}{c}\text { Komitmen } \\
\text { Organisasi }\end{array}$ & $\begin{array}{c}\text { Kinerja } \\
\text { Manajerial }\end{array}$ \\
\hline Partisipasi Anggaran & & & 0,623 \\
\hline $\begin{array}{l}\text { Komitmen } \\
\text { Organisasi }\end{array}$ & & & 0,243 \\
\hline Kinerja Manajerial & & & \\
\hline KO*P & & & 0,093 \\
\hline
\end{tabular}

Sumber: Data kuesioner, diolah dengan SmartPLS, 2018

\section{$\mathrm{R}$ Square (R2 )}

Nilai R Squre merupakan koefisien determinasi pada konstruk endogen. Dengan kriteria nilai R Square sebesar 0.67 (kuat), 0.33 (moderat), dan 0.19 (lemah) (Ghozali, 2015). Tabel 4.5 merupakan hasil estimasi R Square (R2) dengan menggunakan SmartPLS versi 3.2.7 untuk konstruk endogen yaitu Kinerja Manajerial (KM).

\section{Tabel 6}

Nilai $R$ Square

\begin{tabular}{|l|l|l|}
\hline & R Square & R Square Adjusted \\
\hline Kinerja Manajerial & 0,699 & 0,676 \\
\hline
\end{tabular}

Sumber: Data kuesioner, diolah dengan SmartPLS, 2018

Tabel 6 menunjukan nilai R Square (R2) untuk variabel KM diperoleh sebesar 0,699. Hasil ini menunjukan bahwa $69.9 \%$ variabel Kinerja Manajerial (KM) dipengaruhi oleh variabel Partisipasi Anggaran, Komitmen Organisasi (KO), dan Komitmen Organisasi dengan Partisipasi Anggaran (KO*P). Dan memiliki hubungan yang valid serta kuat karena memiliki nilai R Square diatas 0,67.

\section{Predictive relevance (Q2)}

Untuk menguji inner model yaitu dengan melihat predictive relevance (Q2 ). Uji ini dilakukan untuk mengetahui kapabilitas prediksi dengan prosedur blindfolding. Dan memiliki kriteria apabila nilai yang didapatkan (Ghozali, 2015)yaitu 0.02 (kecil), 0.15 (sedang), dan 0.35 (besar). 


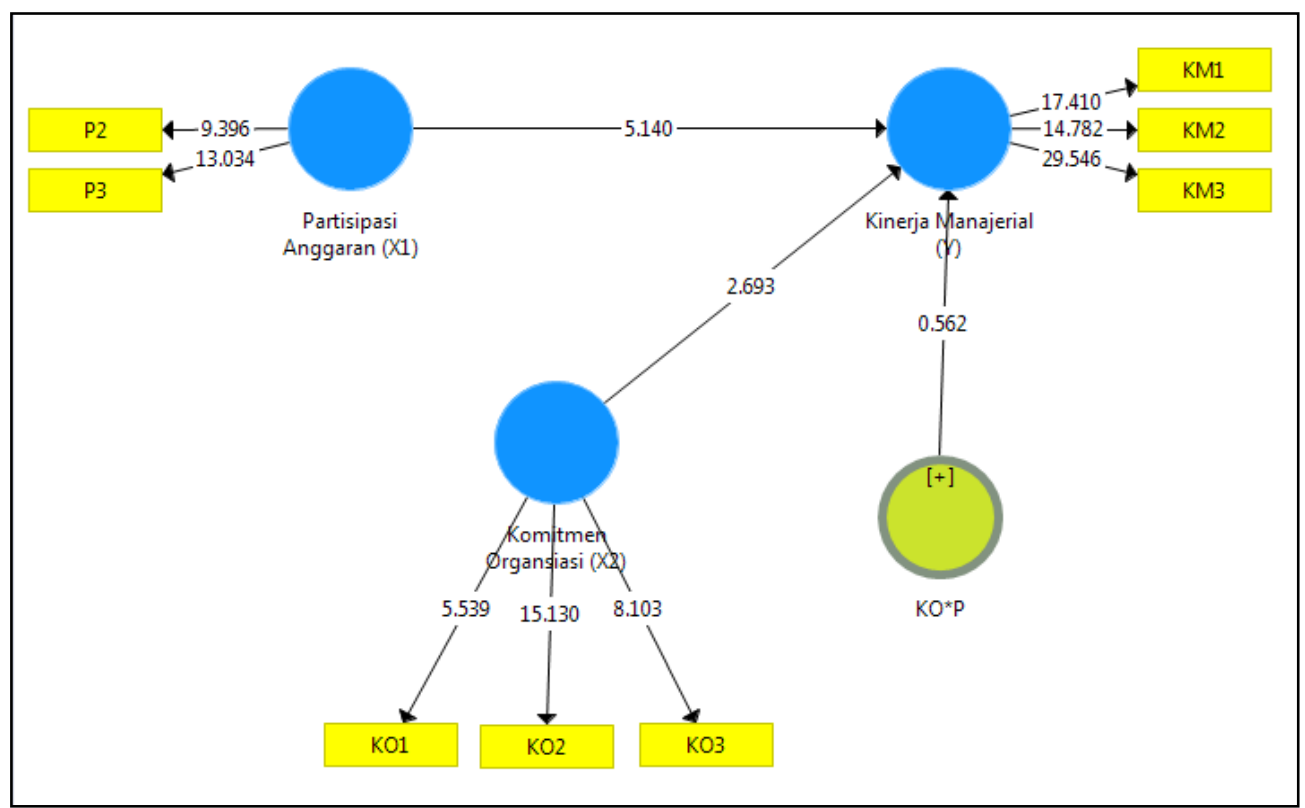

Gambar 7

Hasil Blindfolding Calculation

Sumber: Data kuesioner, diolah dengan SmartPLS, 2018

Tabel 7

Hasil Blindfolding Calculation

\begin{tabular}{|l|c|c|c|}
\hline & SSO & SSE & $Q^{2}$ \\
\hline Kinerja Manajerial & 126.000 & 60.426 & 0,525 \\
\hline Komitmen Organisasi & 126.000 & 126.000 & \\
\hline Moderating effect & 252.000 & 252.000 & \\
\hline Partisipasi Anggaran & 84.000 & 84.000 & \\
\hline
\end{tabular}

Sumber:Data kuesioner, diolah dengan SmartPLS, 2018

Gambar 7 dan Tabel 7 terlihat bahwa hasil Q2 pada variabel Kinerja Manajerial (KM) memiliki nilai sebesar 0.525. Hal tersebut menunjukan bahwa Partisipasi Anggaran (P), Komitmen Organisasi (KO), dan Komitmen Organisasi dengan Partisipasi Anggaran memiliki relevansi prediktif yang besar untuk Kinerja Manajerial (KM).

\section{Pengujian Hipotesa}

Parameter signifikansi yang diestimasi akan memberikan informasi mengenai hubungan antar variabel penelitian. Dasar yang dapat digunakan dalam menguji hipotesis yaitu dengan melihat output uji hipotesis pada path coefficient dengan menggunakan prosedur bootstrapping. 
Tabel 8

Hasil Bootstrapping Calculation

\begin{tabular}{|l|c|c|c|c|c|}
\hline \multicolumn{1}{|c|}{ Hypothesis } & $\begin{array}{c}\text { Original } \\
\text { Sample (0) }\end{array}$ & $\begin{array}{c}\text { Sample } \\
\text { Mean (M) }\end{array}$ & $\begin{array}{c}\text { Standard } \\
\text { Deviation } \\
\text { (STDEV) }\end{array}$ & $\begin{array}{c}T \\
\text { Statistics }\end{array}$ & PVa/ues \\
\hline $\begin{array}{l}\text { Partisipasi } \\
\text { Anggaran -> } \\
\text { Kinerja Manajerial }\end{array}$ & 0,645 & 0,646 & 0,083 & 7,730 & 0,000 \\
\hline $\begin{array}{l}\text { Komitmen } \\
\text { Organisasi } \rightarrow> \\
\text { Kinerja Manajerial }\end{array}$ & 0,252 & 0,263 & 0,065 & 3,860 & 0,000 \\
\hline K0*P -> KM & 0,071 & 0,066 & 0,037 & 1,943 & 0,029 \\
\hline
\end{tabular}

Sumber: Data kuesioner, diolah dengan SmartPLS, 2018

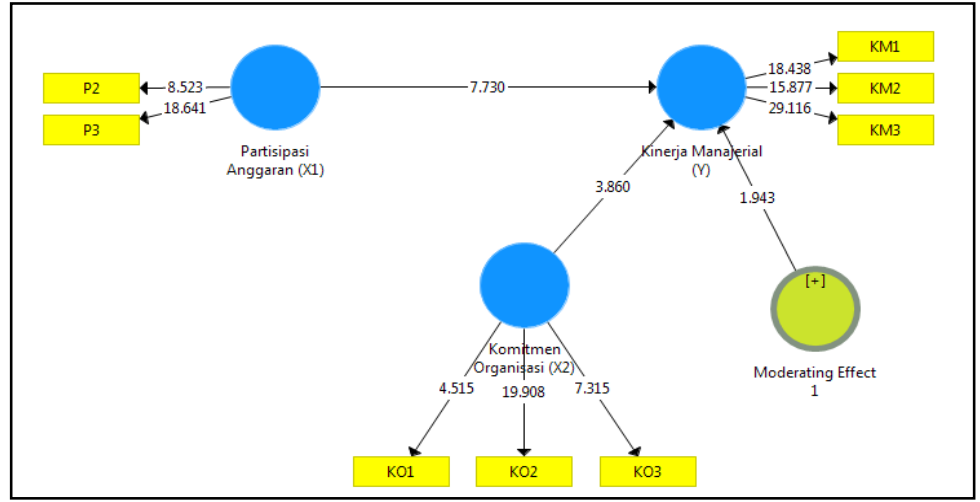

Gambar 8

Hasil Bootstrapping Calculation

Sumber: Data kuesioner, diolah dengan SmartPLS, 2018

\section{Pengujian Partisipasi anggaran berpengaruh terhadap kinerja manajerial.}

Dalam Tabel 8 hasil pengujian hipotesis satu menunjukan bahwa hubungan variabel Partisipasi Anggaran ( $P$ ) dengan Kinerja Manajerial (KM) menunjukan nilai original sample sebesar 0,645 . Nilai original sample yang positif menunjukan bahwa Partisipasi Anggaran ( $P$ ) memiliki hubungan yang positif dengan Kinerja Manajerial (KM). Variabel partisipasi anggaran memiliki nilai t sebesar 7,730 nilai tersebut lebih besar dari t-tabel $(1,96)$. Serta memiliki nilai $p$ value sebesar 0,000 sesuai dengan kriteria nilai $p$ value (kurang dari 0,05). Hasil analisis tersebut menunjukan bahwa partisipasi anggaran memiliki pengaruh positif dan signifikan terhadap kinerja manajerial. Sesuai dengan hipotesis pertama dimana partisipasi anggaran memiliki pengaruh terhadap kinerja manajerial. Hal tersebut menunjukan bahwa hipotesis pertama diterima. Artinya bahwa partisipasi dalam penyusunan anggaran yang mengikutsertakan pejabat struktural sangat mempengaruhi kinerja manajerial pada salah satu Perguruan TinggiSwasta di Jakarta. 
Didukung dengan hasil analisis deskriptif berdasarkan proporsi tanggapan responden terhadap variabel partisipasi anggaran yang menunjukan bahwa $87 \%$ responden menyatakan setuju terhadap variabel partisipasi anggaran. Artinya, dengan adanya partisipasi anggaran tersebut akan mendorong para manajer dan kepala bagian untuk bertanggung jawab terhadap masing-masing tugas yang diembannya sehingga para manajer dan kepala bagian akan meningkatkan kinerjanya agar mereka dapat mencapai sasaran atau target yang telah ditetapkan dalam anggaran.

Hasil penelitian ini sesuai dengan hasil penelitian terdahulu (Maria, 2013)hasil penelitiannya menunjukkan bahwa partisipasi anggaran memiliki pengaruh positif terhadap kinerja manajerial, walaupun analisis data dan objeknya berbeda.

\section{Pengujian Komitmen organisasi berpengaruh terhadap kinerja manajerial.}

Pada Tabel 4.7 hasil pengujian hipotesis kedua menunjukan bahwa hubungan komitmen organisasi (KO) dengan Kinerja Manajerial (KM) memiliki nilai original sample sebesar 0,252. Nilai original sample yang positif menunjukan bahwa Komitmen Organisasi memiliki hubungan yang positif dengan Kinerja Manajerial (KM). Kemudian variabel Komitmen Organisasi memiliki nilai t sebesar 3,860 nilai tersebut lebih besar dari ttabel $(1,96)$. Serta memiliki nilai $p$-value sebesar 0.004 sesuai dengan kriteria nilai $p$-value (kurang dari 0,05). Hasil analisis tersebut menunjukan bahwa Komitmen Organisasi memiliki pengaruh yang signifikan terhadap kinerja manajerial. Sesuai dengan hipotesis kedua dimana komitmen organisasi berpengaruh terhadap kinerja manajerial. Hal tersebut menunjukan bahwa hipotesis dua diterima, ini berarti pejabat struktural salah satu Perguruan Tinggi swasta di Jakarta memiliki komitmen yang tinggi terhadap instansi. Suatu komitmen merupakan suatu sikap yang menggambarkan suatu loyalitas karyawan pada organisasi dan proses berkelanjutan dimana anggota organisasi memberikan perhatiannya terhadap organisasi dan keberhasilan dan kemajuan untuk mencapai tujuan, nilai-nilai serta sasaran organisasi.

Penelitian sebelumnya oleh (Dwi, 2013) tentang pengaruh partisipasi penyusunan anggaran terhadap kinerja manajerial dengan komitmen organisasi sebagai variabel moderating pada Perusahaan Daerah Air Minum (PDAM) sekaresidenan surakarta. Hasilnya komitmen organisasi berpengaruh positif dan signifikan terhadap hubungan partisipasi penyusunan anggaran dengan kinerja manajerial.

\section{Pengujian Komitmen organisasi memoderasi hubungan antara partisipasi anggaran terhadap kinerja manajerial.}

Pada Tabel 8 hasil pengujian hipotesis ketiga menunjukan bahwa hubungan komitmen organisasi (KO) dengan Partisipasi Anggaran (P) 
memiliki nilai original sample sebesar 0,093. Nilai original sample yang positif menunjukan bahwa Komitmen Organisasi memiliki hubungan yang positif dengan Kinerja Manajerial (KM). Kemudian variabel Komitmen Organisasi memiliki nilai t sebesar 1,943. Serta memiliki nilai $p$-value sebesar 0.029 sesuai dengan kriteria nilai $p$-value (kurang dari 0,05). Hasil analisis tersebut menunjukan bahwa Komitmen Organisasi dengan partisipasi signifikan.

Sesuai dengan hipotesis ketiga komitmen organisasi dengan partisipasi anggaran, dapat disimpulkan bahwa pengaruh komitmen organisasi terhadap hubungan partisipasi anggaran dengan kinerja manajerial dapat diterima. Komitmen organisasi dalam penelitian ini dapatmemoderasi hubungan antara partisipasi anggaran dengan kinerja manajerial. Artinya ketika para manajer dan karywan mengejar kepentingan organisasi maka individu tersebut dalam penyusunan program kerja akan ikut berpartisipasi dalam menyusun program kerja dan anggaran agar dapat mencapai target/tujuan yang telah ditetapkan oleh instansi, dengan adanya pemoderasian tersebut dapat meningkatkan kinerja manajerial salah satu Perguruan TinggiSwasta di Jakarta.

Hasil ini sejalan dengan penelitian dari (Dwi, 2013) tentang pengaruh partisipasi penyusunan anggaran terhadap kinerja manajerial dengan komitmen organisasi sebagai variabel moderating pada Perusahaan Daerah Air Minum (PDAM) sekaresidenan surakarta. Hasil penelitiannya menunjukkan komitmen organisasi berpengaruh positif dan signifikan terhadap hubungan partisipasi penyusunan anggaran dengan kinerja manajerial.

\section{SIMPULAN}

\section{KESIMPULAN}

Berdasarkan hasil penelitian yang telah di bahas pada bab sebelumnya tentang pengaruh partisipasi anggaran terhadap kinerja manajerial dengan komitmen organisasi sebagai variabel moderating, maka dapat ditarik kesimpulan sebagai berikut:

1. Terdapat pengaruh positif dari partisipasi anggaran terhadap kinerja manajerial salah satu Perguruan Tinggi Swasta di Jakarta. Hal tersebut dibuktikan dengan $\mathrm{t}$ statistik variabel partisipasi anggaran yang memiliki nilai 5,140 dimana lebih tinggi dari t tabel sebesar 1,96 dengan nilai signifikan 0,000 yang berarti lebih kecil dari 0,05 dan memiliki original sampel yang positif 0,623 . Semakin tingginya partisipasi anggaran maka semakin tinggi pula kinerja manajerial pada perguruan tinggi swasta di Jakarta.

2. Komitmen organisasi berpengaruh positif terhadap kinerja manajerial salah satu perguruan tinggi swasta di Jakarta. Hal tersebut dibuktikan pada analisis data t statistik yang memiliki nilai 2,693 dan nilai tersebut 
lebih tinggi dari t tabel yaitu 1,96 dan variabel komitmen organisasi memiliki nilai signifikan yaitu 0,004 dimana nilai ini lebih rendah dari 0,05, selain itu variabel ini memiliki original sample yang positif 0,243. Artinya pejabat struktural salah satuPerguruan Tinggi Swasta di Jakarta memiliki komitmen organisasi yang tinggi untuk instansi.

3. Variabel komitmen organisasi dapat memoderasi hubungan partisipasi anggaran terhadap kinerja manajerial salah satu perguruan tinggi swasta di Jakarta. Hipotesa ini dibuktikan oleh nilai t statistik sebesar 1,973 nilai tersebut lebih tinggi dari nilai t tabel 1,96 dan dapat dilihat juga nilai $p$ value sebesar 0,029 lebih rendah dari nilai signifikan yaitu 0,05. Artinya hipotesa ketiga signifikan dan dapat diterima, ini berarti menunjukkan bahwa pejabat struktural perguruan tinggi swasta di Jakartalebih mementingkan kepentingan organisasi daripada kepentingan individu. Pejabat struktural perguruan tinggi swasta di Jakartadalam penyusunan program kerja dan anggaran selalu ikut berpartisipasi serta akan meningkatkan kinerjanya agar dapat mencapai target/tujuan yang telah ditetapkan oleh instansi.

\section{SARAN}

Berdasarkan hasil penelitian yang telah disimpulkan, maka saran yang diharapkan dapat bermanfaat bagi salah satu Perguruan Tinggi Swasta di Jakarta yaitu:

1. Disarankan kepada pejabat struktural lebih berpartisipasi dalam menyusun program kerja dan anggaran agar memberikan pendapatnya pada saat penyusunan program kerja dan anggaran, dengan adanya pendapat dari masing-masing pejabat struktural yang ada di perguruan tinggi swasta di Jakarta dapat meningkatkan kinerja manajerial dan juga mencapai tujuan dari Institusi.

2. Diharapkan rektor, dekan fakultas, kepala bagian, kepala bagian program studi, sekretaris dan humas yang ikut berpartisipasi dalam penyusunan program kerja dan anggaran, bisa saling memberikan pengaruh pada saat penyusunan program kerja dan anggaran akhir dengan cara meningkatkan inisiasi dalam memberikan pendapat dan juga lebih meningkatkan kontribusinya dalam penyusunan program kerja dan anggaran.

3. Rektor Perguruan Tinggi Swasta di Jakarta seharusnya lebih aktif lagi dalam memotivasi para pelaksana penyusunan program kerja dan anggaran, mulai dari memberikan pengarahan dan penjelasan tentang tujuan-tujuan yang ingin dicapai oleh Instansi, dan juga mereview usulan/masukan yang diberikan serta melakukan evaluasi pada setiap kinerja yang dilakukan oleh para manajer. 


\section{DAFTAR PUSTAKA}

Anthony N, R., \& Govindarajan, V. (2011). Sistem Pengendalian Manajemen. Jilid 2. Tanggerang: Karisma Publishing Group.

Armstrong, M. (2009). Armstrong's Handbook of Human Resource Management Practice: 11th ed. London: Kogan Page.

Basri. 2011. Pengaruh Partisipasi Anggaran Terhadap Senjangan Anggaran Dengan Asimetri Informasi Sebagai Variabel Moderasi, Skripsi Universitas Hasanuddin Makassar.

Dwi, A. (2013). Pengaruh Partisipasi Penyusunan Anggaran Terhadap Kinerja Manajerial Dengan Komitmen Organisasi Sebagai Variabel Moderating Pada Perusahaan Daerah Air Minum (Pdam) Se Karesidenan Surakarta.

Galih, W. (2016). Pengaruh Partisipasi Penyusunan Anggaran Terhadap Kinerja Manajerial Pada Sekolah Menengah Negeri di Tegal. Esensi, 6(2), 199-212. https://doi.org/10.15408/ess.v6i2.3575

Garrison, Ray H, Norren, Brewer. (2013). Akuntansi Manajerial. Jakarta: Salemba Empat.

Ghozali, I. (2015). Partial Least Squares Konsep, Teknik Dan Aplikasi Menggunakan Program SmartPLS 3.0, Edisi 2. Partial Least Squares Konsep, Teknik Dan Aplikasi Menggunakan Program SmartPLS 3.0, Edisi 2.

Hansen, Don R. dan Mowen, M. M. (2013). Cornerstones of Cost Management. Cengange Learning, United States of America: Thomson South-Western.

Kurniawan, Muhammad. (2013). Pengaruh Komitmen Organisasi, Budaya Organisasi, Dan Kepuasan Kerja Terhadap Kinerja Organisasi Publik, Jurnal Fakultas Ekonomi Universitas Negeri Padang.

Maria, H. (2013). Pengaruh Penyusunan Anggaran Partisipatif Terhadap Kinerja Manajerial Pada Perguruan Tinggi Swasta (studi empirik pada Perguruan Tinggi Swasta Kopertis Wilayah IX Sulawesi).

Momeni, et. al. (2012). The Relationship between Organizational Culture and Organizational Commitment in Staff Department of General Prosecutors of Tehran, International Journal of Business and Social Science. Vol. 3, No. 13.

Noor, Juliansyah. (2014). Analisis Data Penelitian Ekonomi \& Manajemen, Jakarta: PT Gramedia.

Novaliastuti, Masiaga. (2015). Pengaruh Partisipasi Penyusunan Anggaran Terhadap Kinerja Aparat Pemerintah Daerah Kepuasan Kerja Sebagai Variabel Moderating Pada Skpd Kabupaten Pohuwato, Jurnal Volume 3, Universitas Gorontalo.

Riandy, cahyadi sugiarto, \& Jesica, H. (2010). Pengaruh Komitmen Organisasi, Gaya Kepemimpinan, Dan Ketidakpastian Lingkungan Terhadap Hubungan Partisipasi Anggaran Dengan Kinerja Manajerial. 
Jurnal akuntansi kontemporer, 2(2), 171-189.

Sopiah. (2008). Prilaku Organisasional. Yogyakarta: Andi.

Soekidjan, Soegiarto. (2009). Komitmen Organisasi Sudahkah Menjadi Bagian Dari Kita, Jakarta : Rineka Cipta.

Sugiyono. (2014). Metode Penelitian Pendidikan Pendekatan Kuantitatif, Kualitatif Dan R\&D. Bandung: Alfabeta.

Supriyatno. (2010). Pengaruh Partisipasi Pejabat Struktural dalam Penyusunan Anggaran, Komitmen Organisasi, Profesionalisme dan Struktur Organisasi pada kinerja Manajerial Pemerintah Kota Denpasar, Tesis S2 Universitas Udayana.

Tanjung, H. M. (2017). Pengaruh Partisipasi Anggaran, Komitmen Organisasi Dan Motivasi Terhadap Kinerja Manajerial Pada Bumn Ptpn V Pekanbaru. Jom Fekon, 4(1), 1583-1597.

Wulandari, Diana Eka dan Ikhsan Budi Riharjo. (2016). Pengaruh Penganggaran Partisipatif terhadap Kinerja Manajerial dengan Komitmen Organisasi dan Gaya Kepemimpinan, Jurnal Ilmu dan Riset Akuntansi. Vol 5, No 4, h. 1-21.

Zahro, H., \& Januarti, I. (2016). Pengaruh partisipasi anggaran terhadap kinerja manajerial dengan persepsi keadilan anggaran dan komitmen tujuan anggaran sebagai variabel intervening (Studi Kasus pada Universitas Diponegoro). Jurnal Akuntansi Dan Auditing, 13(2), 125154. 